\title{
Changing Institutional Rules
}

\author{
The Evolution of Corporate Philanthropy, 1883-1953
}

\author{
MARK SHARFMAN \\ University of Oklahoma
}

Corporate philanthropy is considered to be an integral part of corporate social performance; however, this was not always the case. At one time, the use of corporate funds for philanthropy was illegal. This article uses institutional theory to examine the evolution of corporate philanthropy from its illegal status to the time when it became both legal and expected behavior on the part of business firms. Because institutional rules rarely change as dramatically as did those governing corporate philanthropy, an examination of these changes provides a unique opportunity to begin development of more generalized theory concerning change in the institutional structure of business.

The test there again is not whether it [an expenditure] is bona fide but whether, as well as bona fide, it is done within the ordinary scope of the company's business and whether it is reasonably incidental to the carrying on of the company's business for the company's benefit. . . It seems to me that charity has no business to sit at boards of directors qua charity.

(Hutton v. West Cork Railway Co., 1883, emphasis added)

It seems to us that just as the conditions prevailing when corporations were originally created required they serve public as well as private interests, modern conditions require that corporations acknowledge social

AUTHOR'S NOTE: The author thanks Thomas Jones, T. S. Pinkston, Nim Razook, Teresa Shaft, Donna Wood, Dan Wren, and three anonymous reviewers for their helpful comments on this and earlier drafts of this article.

BUSINESS \& SOCIETY, Vol. 33 No.3, December 1994 236-269

(C) 1994 Sage Publications, Inc

236 
as well as private responsibilities. ... Such expenditures may be readily justified ... in terms of actual survival of the corporation.

(A. P. Smith Manufacturing Co. v. Barlow et al., 1953, emphasis added)

At Phillips, we care about the people around us.

(1991 Phillips 66 television commercial regarding the company's philanthropic activities)

It is hard to watch television, listen to the radio, or read a newspaper or magazine without noticing examples of firms trying to demonstrate their corporate "citizenship" à la the Phillips commercial quoted here. This behavior manifests in many ways but specifically in the billions of dollars that business firms donate annually to philanthropic causes (Platzer, 1990). American firms have found myriad ways to tout their philanthropic activities as part of image marketing campaigns, and the promotion of corporate philanthropic behavior as a marketing tool continues to increase (Wood, 1990). This overt promotion of corporate largess was not always the case. In fact, at one time the use of any corporate funds for philanthropic purposes was illegal. What is theoretically intriguing is how corporate philanthropy evolved from being illegal to being the top of the "pyramid of corporate social responsibility" (Carroll, 1991, p. 42). Using institutionalization theory (e.g., Meyer \& Rowan, 1977; Zucker, 1988) as its basis, this article presents a historical/institutional analysis of the changes that occurred as corporate philanthropy changed from being illegal to being a legitimate, integral part of the social performance of American business firms. Because institutional rules rarely change as dramatically as did those surrounding corporate philanthropy, an examination of this evolution provides a unique opportunity to begin the development of more generalized theory concerning change in the institutional structure (rules) of business.

The first two quotations that introduce this article define the change in the role of corporate philanthropy and delimit the period of study for this analysis. The ruling in the West Cork Railway case was not the first ruling in this area (see Davis et al. v. Old Colony Railroad Co., 1881), and it did not address directly the issue of corporate philanthropy. However, this case has been widely accepted as precedent for the courts' application of the doctrine of ultra vires (behavior beyond the incidental powers of the firm) 
regarding acts of corporate philanthropy. Various courts used this doctrine to severely limit managerial power and to put a stop to corporate donations. The precedent was set aside formally when the U.S. Supreme Court refused to review the New Jersey Supreme Court's decision in the A. P. Smith case. In so doing, the U.S. Supreme Court finally and formally affirmed the corporation's right to make donations-something the greater society had accepted for some time. This article examines the complete change in the societal role of corporate philanthropy that occurred during the 70-year period between these two landmark decisions.

This article makes two major advances over previous research. First, even the premier works on American philanthropy (e.g., Andrews, 1952; Bremner, 1987; Heald, 1970) do not provide a theoretical framework whereby researchers can understand the evolution of corporate philanthropy. The application of institutional and other theories fills that gap. Second, by building on Meyer and Rowan's (1977) ideas of institutional legitimacy and on Zucker's (1988) notions of institutional change, this article begins the development of more generalized theory concerning change in the institutional structure within which business operates.

This article examines institutional change in a relatively novel way. Other authors have investigated change in the institutional environment and the effect such change has had on organizations (e.g., Leblebici, Salancik, Copay, \& King, 1991; Scott \& Meyer, 1983). This article is consistent with Scott's (1987) suggestion that more research is needed on the "determinants of institutional systems themselves" (p. 508). Additionally, this article extends the same research tradition as that of Wood (1986) because its focus is in part on how organizations changed the institutional structure (rather than vice versa).

Historical analysis is the method of choice for the investigation of the evolution of corporate philanthropy. Jackson (1990) argued that "history ... is a central part of analyzing any contemporary institution" because "institutions are the accumulation of historical actions that become embedded in our social structures" (p. 13). Zald (1990) further suggested that historical analysis is an essential part of organizational theory:

The isolation of organizational theory from historical context and analysis impedes the progress of organizational studies. It leads to overgeneralization, ignoring historical alternatives and misspecification of causation. (p. 101)

To understand the nature of an institutional structure today, this article asserts that researchers must understand the historical context within which that structure developed. 


\section{Institutionalization and Institutional Change}

To analyze how the institutional role of corporate philanthropy changed, it is necessary to develop some common understanding about the concepts to be employed in the analysis. Because this article addresses institutional structure change, the first concept with which we must be familiar is that of an institution. Hughes (1939) described institutions as features of society that "outlast biological generations or survive drastic social changes that might have been expected to bring them to an end" (p. 283). Next, it is important to understand the process by which a social phenomenon becomes an institution-that is, through the process of institutionalization. Berger and Luckmann (1967) suggested that the development of shared social reality is the source of institutionalization. This shared social reality entails the collective development of rules within which society functions. About this idea, Meyer and Rowan (1977) wrote that

such rules may be simply taken for granted or may have the force of law (Starbuck, 1976). Institutionalization . . . enter[s] social life primarily as facts that must be taken into account by actors. Institutionalization involves the processes, obligations or actualities [that] come to take on rulelike status in social thought and action. (p. 342)

Giddens (1982) maintained that even when these social constructions do not have the force of law behind them, they are compelling because they have a "virtual existence" and have been "instantiated ... in the structure of social systems and in the memory traces (reinforced or altered in the continuity of daily social life) that constitutes the knowledgeability of social actors" (p. 9). Scott and Meyer (1983) suggested that conformance to these rules is essential if firms "are to receive support and legitimacy from the environment" (p. 140), as the latter are essential for organizational survival (Singh, Tucker, \& House, 1986). The case material presented later describes how the institutional rules governing corporate philanthropy developed and how the practice itself was institutionally legitimated. The nature of legitimacy and legitimization are discussed later in this section.

Next, this article must examine the term institutional analysis, which means an examination of the social structure of a society and the institutions within it. The social structure is the network of rules, norms, laws, beliefs, and so forth that are institutionalized to govern the ways that society operates. A subportion of that social structure governs the ways that networks of organizations and the people within them interact with 
each other (e.g., Meyer \& Rowan, 1977). Zucker (1988) argued that these social networks

are the central means of increasing social system coherence.... Institutionalization is shown to be both a cause of increased coherence in networks and a consequence of the resulting stability in the same networks. (p. 24)

Because this article examines change in institutions within the social structure, the next concept to be addressed is institutional change. Although there may be some fluidity in the rules of both the greater social structure and the subportion that governs business behavior, in general these rules appear to be relatively inertial and impervious to change. The inertia stems from the fact that these rules become embedded (and hence stable) in the fabric of society (e.g., Granovetter, 1985). Regarding the processes of institutional change, Zucker (1988) proposed that

external sources of change will tend to be experienced as shocks that disrupt the systems or as reservoirs of potential innovation that may produce change through gradual diffusion.... Institutionalized rules carry the seeds of their own disruption by specifying conditions under which their legitimacy should be modified. (pp. 23-24)

The institutional change of interest to this article is institutional legitimization of corporate philanthropy, and so a working definition of legitimacy also is necessary. For business practices to become institutionalized, they must gain legitimacy but it is not clear how that happens. Even defining the nature of legitimacy as an institutional change is not easy to do. Scott and Meyer (1983) argue that "legitimacy is a term of uncertain meaning" (p. 200), suggesting that organization studies researchers have not reached consensus on the definition of the construct. These authors offer the following definition of legitimacy, which this article adopts:

A completely legitimate (practice) would be one about which no question could be raised. Every goal is specified, unquestionable, and reasonably important. Every technical means is adequate and has no alternative. . . . Every aspect . . . is complete and without alternative including the ... link to its ... field of activity or implementation. (p. 201)

The legitimacy of business practices and, by implication, the legitimacy of business organizations themselves are a source of ongoing concern. On this point, Davis (1973) suggests that

society grants legitimacy and power to business. In the long run, those who do not use the power in a manner which society considers responsible will tend to lose it. (p. 314) 
Wood (1991) takes this argument even further by suggesting that the "Principle of legitimacy ... defines the institutional relationship between business and society" (p. 696).

\section{Theoretical Framework}

With the previous definitions in mind, this section provides the theoretical basis with which this article strives to explain how and why corporate philanthropy evolved from illegal to being both legitimate and the top of Carroll's (1991) pyramid of corporate social responsibility. Although it is clear that corporate philanthropy is still considered by many observers as discretionary or optional (cf. Wood, 1991), it is often the most visible of the firm's social performance. As is shown in the case material presented later, this article suggests that the legitimization of corporate philanthropy happened because it fulfilled a very functional role in society. This article argues that, in a manner consistent with Parsons's (1960) theories about social action, the evolution of corporate philanthropy helped society reattain equilibrium as a reaction to the major changes of the period. During the latter part of the 19th century, the United States was undergoing a profound set of social and political changes. The growth of the cities created a wide variety of social ills and needs that required attention-often beyond what various units of government were able to provide. Lloyd (1986) suggested that one of society's responses to these problems was to expand the role of business from provider of goods, service, and income to an additional role of provider of resources to solve society's problems. Consistent with Aram (1989), it can be argued that society used corporate philanthropy to help resolve the conflict between a collective desire to be of assistance to one's fellow citizens in need and the collective philosophy of "individualism [which was] the foundation of American society" (p. 280). By expanding what corporations could do in terms of corporate philanthropy, society was in part able to "address the potential limitations, dysfunctions, and unmet needs that arose" during the period (cf. Aram, 1989, p. 280). If corporations had limited ability to engage in philanthropic activities, then society could increase the level of social needs that were met without increasing government's role.

Once society began to change its perceptions of corporate philanthropy after the Steinway case, several sets of forces facilitated incremental changes in the legitimization of corporate philanthropy (Steinway $v$. Steinway \& Sons et al., 1896; see the section titled "The Beginnings of 
Corporate Philanthropy: 1875-1900" for a description of the Steinway case). In the face of several restraining forces, both directly and through a "contagion of legitimacy" (Zucker, 1988, p. 24), the driving forces gradually created the pathways that increased the scope of what was considered legitimate corporate philanthropy. Zucker (1988) defines the contagion of legitimacy as a gradual diffusion process. She suggests that

once a single element becomes institutionalized ... other associated roles, acts and even procedures become infected with legitimacy. The more tightly integrated the structure, the more rapidly legitimacy spreads (Hernes, 1976). Thus a few stable legitimate elements tend to proliferate over time through a contagion of legitimacy to other efforts tightly coupled to them. Independent of any further institutionalization efforts, institutionalization within a formally organized collectivity tends to increase. (p. 24)

In the case of corporate philanthropy, this article shows that the Steinway case opened the door for the legitimization of the practice. American society was in the process of more finely differentiating the functions of government and business organizations. As the corporate business form became more integrated in society and more firms wished to make corporate donations, what was considered allowable philanthropy gradually increased as more and more corporate donative behavior was "infected" with legitimacy.

This article also shows how the confluence of five sets of theoretically explainable driving forces were integral to the evolution of corporate philanthropy. These forces were (a) the altruistic actions of social actors (cf. Reilly, 1990), (b) the strategic use of public policy by charitable organizations and by business firms (e.g., Mitnick, 1981; Wood, 1986), (c) the actions by firms facing institutional isomorphic pressures (Dimaggio \& Powell, 1983), (d) the organizational acquiescence to institutional pressures (cf. Oliver, 1991), and (e) the changes in the controls governing the social structure (Smelser, 1968).

None of the five sets of forces in themselves proved sufficient to change the role of corporate philanthropy. Rather, coupled with the major changes occurring in society, they were able to facilitate corporate philanthropy's evolution. Several acute and chronic social problems helped create a context of need for the change in corporate philanthropy's role. Jeperson (1989) argued that only under conditions of extreme environmental shock is an institution likely to change. In the case of corporate philanthropy, it took far more to make enduring changes in societal beliefs about the propriety of corporate giving than a single environmental upheaval, war, or economic depression. Multiple occurrences of each of these calamities plus several other social upheavals were stimuli for the forces that led to 
the change in the perception of corporate philanthropy. For corporate philanthropy, the presence of multiple environmental shocks proved instrumental for the forces driving for corporate philanthropy's legitimization to overcome some of the forces attempting to restrain the change. The various calamities increased the need for business participation through charitable contributions so that society could no longer ignore corporations as potential donors. Further, the pressures brought on by industrialization, immigration, and urbanization stretched the infrastructure of charity in the United States to a virtual breaking point. Efforts by business, government, charities, and private citizens in response to these issues also provided impetus for the forces pushing for the evolution of corporate philanthropy.

\section{The Evolution of Corporate Philanthropy}

Organizational philanthropy is not a new phenomenon. Church support of the poor and of education started during the Middle Ages. During hard times, the guilds of medieval Europe took care of their members. In Europe, tax-supported attention to the poor and ill was a limited feature of public life as early as the 17th century. By the middle of the 19th century, widespread philanthropic support of education, social welfare, and the poor had begun (Bremner, 1987). Support for these philanthropic activities came from tax dollars, individual philanthropic donations, or donations to churches. At this time in history, corporate participation in philanthropic activities was very limited.

\section{THE CONTEXT FOR CORPORATE PHILANTHROPY DURING THE LATE 19th CENTURY}

There are several reasons why few corporations of the time participated directly in philanthropic endeavors. Even by the end of the 19th century, few corporations existed or, in practice, there was little difference between the affairs of the corporation and the affairs of the owner. During the late 1800 s, many wealthy individuals simply donated their own funds; if they owned a corporation, they left its assets alone. Second, in the ruling in the 1837 Charles River Bridge case, the courts found that "corporate acts were contractual, limited and specific and that any act beyond chartered powers was prohibited" (i.e., ultra vires) (Wren, 1983). Therefore, the corporations of the period were reluctant to use corporate funds for anything that was not directly related to their chartered purpose. 
Ultra vires was first applied to corporate philanthropy in the 1881 ruling of the Old Colony Railroad case. In this case, the railroad company had financially supported a "world peace jubilee and international music festival" (Wren, 1983, p. 341). Several stockholders sued, claiming that this was an ultra vires action. The company argued that the support was a legitimate expense because the festival had increased business. The courts disagreed and found for the plaintiffs.

Although the Old Colony Railroad case is important for this analysis, it was not the most widely recognized precedent for later cases. The definitive statement about the role of philanthropy in the corporation came in the West Cork Railway case mentioned previously. In this case, the company was being taken over by another firm. As part of the dissolution, the board decided to pay some of the proceeds of the sale to retiring directors as recognition for past services. A stockholder sued, claiming that these payments were gifts-not payment for services rendered. The court upheld the stockholder's suit. Even though the case was not about corporate charity per se, Lord Justice Bowen's ruling (see the quote at the beginning of this article) became the basis for the "principles with respect to corporate donations which have, in general, prevailed in American common law" (Andrews, 1952, p. 230).

\section{THE BEGINNINGS OF CORPORATE PHILANTHROPY: $1875-1900$}

Even though judicial precedent limited the charitable activities of corporations, during the last quarter of the 19th century there was some growth in business-based donations to social and philanthropic organizations. However, instead of engaging in "philanthropy in the sense of some moral guided behavior" (Heald, 1970, p. 8), firms often funded services that would directly benefit their workers and indirectly aid the firm. In many cases, manufacturers (the Pullman Company is the best known) helped to fund local schools, libraries, and so forth located in their so-called company towns. The objective was to attract workers to often remote or undesirable locations-not to fulfill some overriding social agenda.

During this period, a major recipient of corporate largess was the Young Men's Christian Association (YMCA), which by 1890 had established 82 facilities at railroad terminals. Andrews (1952) suggested that the "usual practice at this stage was for railroads to pay about $60 \%$ of the operating budgets for railroad YMCA buildings and the [railroad's] employees making up the remainder" (p. 24). It was argued at the time that although 
this practice was corporate support of charity, it was also business related because railroad employees needed a place to stay during their "turnaround" time from their jobs.

Not all corporate philanthropy of the period was business related. Records from the R. H. Macy Company for 1875 show donations to an orphanage and for 1885 show how the firm sponsored a sale of miniature Statues of Liberty to help pay for the base on which the actual statue stood. Macy's records for 1887 indicated total charitable donations of $\$ 1,084.91$ plus expenses for advertisements in the programs and publications of charitable organizations (Heald, 1970).

Although the R. H. Macy Company was not alone in its support of social needs, the philanthropy of the late 19th century was still largely an individual endeavor (Wren, 1983). Individualized philanthropy was the result of both legal precedents and the dominance of laissez-faire economics as the contemporary paradigm for business. However, during the last quarter of the 19th century, the effects of large-scale immigration and urbanization, coincident with the industrialization of the period, put pressures on corporations to help alleviate the social problems of the era. Wood (1986) argued that the United States was a society that "by the 1880s was agrarian only in the statistical sense" (p. 39). The growth of the cities created a wide variety of social ills and needs that required attention. As mentioned previously, Lloyd (1986) argued that society's response to these problems was to expand the role of business to one with which it was able to aid in the solution of society's problems.

The recessions/depressions of 1873-1877, 1885-1887, and 1892-1894 also compelled corporations toward philanthropy. Each of these economic calamities exacerbated the already difficult situations in the cities. Most of the burden fell on private charities and government, but they did not have the resources to meet all of these exigencies. Limited increases in corporate philanthropic activity were noted during each economic downturn (Bremner, 1987). At the end of the 19th century, several court cases gave limited legitimacy to the growing use of corporate funds for charitable purposes-as long as those donations directly benefited corporate goals. Two of the most definitive rulings can be found in the 1896 Steinway v. Steinway \& Sons et al. and the 1899 Main v. C.B. \& Q. Railroad cases. Consistent with the "business-related" admonition in the Old Colony Railroad case, the courts in these cases upheld the firms' rights to use corporate funds to provide social benefits for employees. In the Steinway case the company had contributed funds to build homes, churches, schools, and public baths for Steinway employees, whereas in the C. B. \& $Q$. Railroad case the firm had contributed to a benefit society for its 
employees. In each case, stockholders claimed these expenditures were charitable and hence ultra vires. The argument made by the companies in both cases was that these expenditures, although charitable, did provide direct benefit to the firm. The courts held that the expenses were "related" to company activities and hence legal and within the incidental powers of the firm (Andrews, 1952). The definition of business related continued to be examined and expanded by the courts as it became the key element in the legal portion of the evolution of the institutional structure surrounding corporate philanthropy.

Not all of the forces of the period had a positive impact on the development of corporate philanthropy. One negative effect of late 19thcentury industrialization was a budding antibusiness sentiment (Bremner, 1987). During the early 1890 s, this sentiment grew to a point at which donations from businesses were sometimes seen as "tainted money." Gladden (1895, p. 886), in his essay of that same name, campaigned against social agencies taking donations from business and went so far as to ask, "Is this clean money? Can any man, any institution knowing its origin touch it without being defiled?"

Gladden's views were not isolated. As an example, during this same time period, the venerable Jane Addams rejected a corporate donation of $\$ 20,000$ for a project for Hull House. She reportedly argued that "the donor's record as an employer made it unthinkable" to accept the donation (Bremner, 1987, p. 108).

Another challenge to corporate philanthropy was raised by the adherents of laissez-faire capitalism who argued that it was immoral (in addition to generally illegal) for the managers to give away corporate funds. The advocates of laissez-faire capitalism represented an odd alliance of religion and economics. According to this philosophy, firms had the right to (and should) do almost anything in a business that would make money (within the law). Wood (1986) argued that this approach to business was justified on religious grounds: "God would provide a sign of grace to those who could count on an eternity in heaven; the sign would be good health, good fortune and, most importantly, the accumulation of material wealth" (p. 49). If wealth was the measure of a person's ability to get into heaven and if managers gave this wealth away, then they impinged on the stockholders' eternal lives.

One additional change occurred during this period that polarized the legal and social conflicts surrounding corporate philanthropy. By the end of the 19th century, the movement toward managerial control and away from owner control of organizations had begun (cf. Fligstein, 1990). As noted earlier, when owners wished to make donations, they did so. 
Because these owners generally were beholding to no one else, there was no conflict. However, when managers tried to make donations using corporate funds, the ambiguity that remained in the still developing manager/owner agency relationship became apparent with the growth in shareholder litigation challenging corporation donations.

\section{PROGRESSIVISM, MUCKRAKERS,} AND PHILANTHROPY: 1900-1915

At the beginning of the 20th century, there was a rise in public awareness of the "injustices and tragedies wrought by industrialization and the social changes that accompanied it" (Wood, 1986, p. 65). This awareness was provoked by a genre of journalists known as the muckrakers (e.g., Mowry, 1972). These journalists sought to right what they perceived to be the wrongs and excesses of the period. Ghent (1902), in his widely read essay titled Our Benevolent Feudalism, argued that most Americans favored big business and that most opinion molders (e.g., schools, churches, and the press) reinforced these views. By 1912, and after a decade of muckraking, the public's opinion, "if not fundamentally hostile, was at any rate skeptical of the methods and objectives of business leadership" (Heald, 1970, p. 43).

Teddy Roosevelt and the Progressive Republicans held national power during the period of the muckrakers. The factors that caused the ascendance of the Republicans also resulted in three major changes that had influence on corporate philanthropic practices. First, there was a rise in the scrutiny of business by the federal government. Even though regulatory bodies had existed for 15 years (cf. McCaw, 1984), it was during this period that Congress enacted several major pieces of regulatory legislation that included enforcement powers (e.g., the 1906 Meat Inspection Act, the 1906 Pure Food Act, the 1914 Clayton Act, and the 1914 Federal Trade Commission Act). Increasingly, business practice was a matter of public debate and discussion. By implication, corporate philanthropic activity was also scrutinized carefully.

The second major change was a vast increase in the number of charitable organizations early in the 20th century. The Progressives and the muckrakers called attention to the plight of the urban poor, which in turn led to the creation of hundreds of new charities. Bremner (1987) described the effect of these changes on philanthropy in the following terms:

Opportunities . . . for giving, already numerous in 1900, increased enormously for the next decade and a half. The continuing vitality of the voluntary principle and a broadening sense of responsibility for improving 
the social environment led to the formation of a host of new national organizations maintained by dues, donations and subscriptions. (p. 117)

The existence of these charities created both opportunities and pressures for corporate philanthropy. The muckrakers and others put pressures on business to use philanthropy judiciously to help gain legitimacy.

In addition to the rise in charitable organizations, the third major change was the development of "scientific" (federated) philanthropy (Bremner, 1987) during the early part of the 20th century. The plethora of charitable organizations created competition among recipients and confusion among donors. It was often difficult for corporations to discern what was and was not a worthy cause, and so many did nothing. For a few wealthy industrialists, creating a foundation that could hire staff, screen charities, and make the appropriate decisions proved to be a workable solution. However, only these wealthy individuals or the largest corporations could use this approach. It was the charitable organizations themselves that realized the need for coordination, not competition. As early as 1870, a group of Jewish welfare agencies banded together in Philadelphia to cooperate on various activities. It was not until 1895 , however, that a similar group in Boston federated specifically for joint fund raising. By 1913, there were broad-scale federated solicitation programs in 16 major cities.

These federated programs exerted two forces on corporate donors. First, their existence clarified the confusion over what was a worthy cause. The federated groups represented a broad range of legitimate charities, and so firms could donate without fear of fraud or charges of favoritism. Second, these federated groups instructed corporations regarding the appropriate amount of charity or funding. Prior to this point, corporate philanthropy was a haphazard activity. According to studies of the period, many firms chose not to give because they did not know how much funding was appropriate (Bremner, 1987).

Despite the pressures on corporations to increase their philanthropic activities, there were still forces present during this period that discouraged donations. The rapid pace of urbanization replaced the company town with much more complex urban areas. As cities increased in size and complexity, it was much more difficult for a charity to argue that any one employer was responsible to help alleviate conditions affecting the local citizenry. The lack of clear standards for giving, coupled with "the growing impersonality of the urban environment, discouraged business philanthropic activity" (Heald, 1970, p. 6).

A further force against corporate philanthropy during this period was the legacy of legal constraints left over from the 19th century. Even though 
the ruling in the Steinway case had broadened corporations' donative discretion, it did not open the door completely. Prior to World War I, two cases were adjudicated that reinforced the limits on corporate donations outside of strictly determined (related) employee welfare areas. In Worthington $v$. Worthington (1905), the firm (a hydraulic pump manufacturer) donated funds to Columbia University for a hydraulic engineering lab. This action was ruled ultra vires because it did not directly affect Worthington's employees or benefit the firm's business. The courts also ruled against the Brinson Railroad Company when the corporation gave a note to raise funds for public school and town development in Georgia (Brinson Railroad v. Exchange Bank et al., 1915). In this case, the court did not see the donations as close enough to the firm's welfare. Although there were other cases during the period that expanded what could be considered business-related philanthropy (e.g., People ex rel. Metropolitan Life Insurance v. Hotchkiss, 1909, in which the company purchased land for an employee hospital that would treat tuberculosis), the legal precedents of the period still did not favor corporate philanthropy.

\section{WORLD WAR I AND ITS AFTERMATH: 1915-1920}

The outbreak of World War I created entirely new pressures for corporate philanthropy. In 1917, the national office of the YMCA held a fund drive to support its work among servicemen. Although detailed records of corporate support for this project do not exist, Andrews $(1952$, p. 26) estimated that as much as $40 \%$ of the $\$ 5$ million raised came from corporations. The American Red Cross, anticipating the enormous needs the war would generate, set a $\$ 100$ million goal for its war finance drive. Support for this drive came directly from President Wilson. In April of 1917, he summoned a group of business and civic leaders to the White House to discuss the Red Cross's needs. Wilson's support was a major impetus for the success of the drive.

Another reason behind the success of the drive was the Red Cross's approach to the legal issues surrounding corporate philanthropy. In a very creative move, the Red Cross identified a way for corporations to make direct contributions while simultaneously not running afoul of the law or offending their stockholders. The organization created a model for what became known as the "Red Cross dividend" (Andrews, 1952). The Red Cross sent any interested corporation a model form letter concerning the corporate declaration of a special dividend. If the firm wished, it couldwith the appropriate modifications-send the letter to its stockholders. The stockholders could then authorize the company to donate this divi- 
dend to the Red Cross war effort. The effort was hugely successful: A total of 148 corporations donated almost $\$ 18$ million. Based on this largess and data indicating that more than 1,100 other corporations donated to the drive, "evidence exists to pinpoint 1917 as the year in which corporation contributions first reached a substantial total in the history of American philanthropy" (Andrews, 1952, p. 28).

It was also during this period that a few states and the federal government began explicitly legalizing what had once been ultra vires. Both types of governments passed enabling legislation that explicitly allowed corporations to make charitable donations without the "relatedness" requirement. Texas passed the first such law in 1917, followed by New York in 1918, Illinois in 1919, and Ohio in 1920 (Andrews, 1952, p. 236). In 1918, Congress authorized nationally chartered banks to make limited contributions directly to the Red Cross drives. By allowing federally chartered banks to contribute, Congress conferred more formal legitimacy on corporate donations.

Another important "legal" event of this time period did not involve legislation or the courts but went a long way toward legitimating corporate philanthropy. In 1918, the Red Cross organized a second national drive. As part of this drive, its New York City corporations committee sent out with its solicitation the text of an opinion on corporate philanthropy from retired Supreme Court Justice Charles Evans Hughes. The following is part of that opinion: "The question is not one of permitting the use of corporate moneys for what are or may be called 'worthy objects' outside the corporate enterprise, but for the maintenance of the very foundation of the corporate enterprise itself' (Andrews, 1952, p. 30). Hughes was the first major legal authority to stress that corporate philanthropy unrelated to business activity was necessary for the survival (legitimization) of business organizations. Apparently, using Justice Hughes's opinion worked: Data from the period indicate that New York City corporations donated almost $\$ 9$ million to the cause (Andrews, 1952).

\section{PHILANTHROPY AND THE PROSPERITY}

OF THE ROARING TWENTIES: 1920-1929

After the end of World War I and with the prosperity of the 1920s, there were several more changes in the evolution of corporate philanthropy. The federated giving programs developed by the Red Cross and several communities led to a national pattern of federated giving. In 1918 the American Association of Community Organizations was formed; it later 
became the Community Chest (the precursor of the United Way). By 1919 there were Community Chest organizations in 40 cities, and by 1929 this number had grown to 350 (Andrews, 1952). Bremner (1987) argued that the Community Chest became a more important outlet for corporate philanthropy than were previous federated giving programs. This was a nationally recognized organization that could both collect corporate donations and make funding decisions. In addition, for the growing list of multicity companies, there was a second advantage: They could deal with philanthropic issues the same way at all of their locations. Heald (1970) argued that, during the 1920s, corporate philanthropy "had become a well-established practice by the end of the decade" (p.119) as a result of the Community Chest movement.

In 1924, the U.S. Chamber of Commerce indirectly conferred additional legitimacy on corporate donations by developing a code of ethics for businesses that included a statement outlining their social obligations to their communities (including philanthropy). By 1925, this statement had been approved by chambers of commerce in 750 cities, which represented more than 300,000 members (Heald, 1970, p. 93). This statement was the first widespread acknowledgment by business people that their social responsibilities included philanthropy.

During the 1920s, the legal status of corporate philanthropy became clearer. There were no court cases during this decade in which corporate philanthropy was declared ultra vires (Andrews, 1952). The massive philanthropy efforts companies put forth during World War I and the advent of federal and state permissive legislation made it difficult for the courts to rule that a behavior that was so welcome during wartime was illegal during peacetime.

However, the courts of this time period were very conservative regarding the specifics of which "donations" could and could not be deducted as expenses from income taxes. Although individuals had been granted income tax deductions for charitable donations in 1917, corporations were allowed to deduct only those donations that had a direct benefit. During the 1920s, the courts struck down deductions for gifts to a university by a bookstore (J. A. Majors, 1926) and gifts to churches, the Boy Scouts, and the Red Cross made in the name of employee relations (E. M. Holt, 1928). The tax court even struck down a donation from Poinsett Mills to the building fund of a church in which approximately $25 \%-30 \%$ of the members were Poinsett employees (Poinsett Mills, 1926). Despite these legal constraints, the definition of a related expenditure did expand somewhat during this period. The year after the Holt case, the Superior 
Pocahontas Coal Company was allowed to deduct funds used to rebuild a damaged church at which its employees comprised 75\%-90\% of the congregation (Superior Pocahontas Coal Co., 1927).

\section{THE GREAT DEPRESSION AND}

THE INTERNAL REVENUE ACT: 1929-1939

The Great Depression had an effect on corporate philanthropy similar to that of World War I. This economic calamity created an enormous set of social needs that the government was not in a position to address fully. Again, business was pressed to do (philanthropically) what it could. In 1931, President Hoover recognized the role of business in meeting the needs created by the Depression. He created a quasi-governmental organization, the Organization for Unemployment Relief, to aid the unemployed and appointed Walter Gifford (president of AT\&T) to head it. Because of his position and connections, Gifford was able to direct a highly successful campaign that raised more than $\$ 100$ million-much of which came directly from major corporations (Eells, 1956).

It was also during 1931 at a national meeting of the Community Chest that the movement toward a corporate tax deduction for donations began. The Community Chest hierarchy believed that such a deduction would provide business with better incentives to donate. However, the election of Franklin Roosevelt caused a setback in this movement. Roosevelt argued that managers did not have the right to "buy goodwill" or to dispose of stockholders' assets without their express consent (Heald, 1970, p. 167).

Still, there was extensive civic pressure on Congress and the executive branch to enact the donation deduction. To help alleviate the pressure, in 1932 the Internal Revenue Service (IRS) loosened its guidelines regarding donations that could be deducted as expenses. An expense could be deducted if there was a reasonable expectation that it would produce any commensurate financial reward.

The fight for the corporate deduction was also being waged in the courts. In 1934, the Old Mission Portland Cement Company made a donation to the San Francisco Community Chest, which it claimed was for goodwill and would increase business (Old Mission Portland Cement Company v. Helvering, 1934). The U.S. Supreme Court disagreed and struck down the deduction, sending a chilling message to the proponents of the corporate donation tax deduction (Andrews, 1952). However, in spite of Roosevelt's objection, in 1935 Congress approved legislation that allowed corporations to donate up to 5\% of their pretax earnings and to deduct that amount on their tax returns. 
The advent of the tax deduction for donations did not seem to have much effect on total corporate philanthropy. Andrews (1952) argued that although data for the period are sketchy, there does not appear to be any marked difference in corporate donations immediately after the tax law change. After reaching a low in 1932, corporate donations began to rise again. However, from 1936 to 1939 , the annual total for corporate giving appears to have remained constant at approximately $\$ 30$ million to $\$ 33$ million. It was not until World War II and the advent of the excess profits tax that corporate giving began to approach modern levels.

\section{WORLD WAR II, THE POSTWAR YEARS,}

AND EXCESS PROFITS TAXES: 1940-1952

The World War I pattern of corporate philanthropy reemerged after the start of prolonged combat in Europe and Asia. These new social needs, the prosperity of wartime productivity, and the positive response to corporate philanthropy efforts during the 1930s all led to renewed efforts during the war. Also, any vestiges of antibusiness sentiment left over from the Depression all but disappeared during the war years. Heald (1970) described this change as follows:

The doubt and defensiveness that characterized business during the depression rapidly faded. Business emerged from the war triumphant, its capacity to perform miracles-under the forced draft of military orders to be sure-no longer in doubt. The renewal of confidence and leadership provided a climate of business opinion in which initiative in exploring the social dimensions of corporate enterprise was encouraged. (p. 206)

This positive view of business discouraged efforts to impede corporate philanthropy. Andrews (1952) and Bremner (1987) reported that corporate donations increased ninefold from 1936 to 1945 , reaching approximately $\$ 270$ million. Although patriotic fervor was part of the reason for the rise in corporate gifts, it is widely argued that the real impetus for the enormous increase in giving was the excess profits tax imposed in 1942 (Andrews, 1952; Bremner, 1987; Eells, 1956; Heald, 1970). This excess profits tax took as much as $90 \%$ of corporate profits over certain levels. By making donations, companies reduced their corporate tax bills while at the same time vastly improving their standing in the community-all for little "real" cost. This tax made philanthropy a "bargain" that prospering corporations could not pass up.

The need for corporate philanthropy did not end with the cessation of hostilities. Rebuilding war-torn Europe became an international priority, 
and business firms did pitch in. However, the repeal of the excess profits tax did remove some impetus for corporate donations. Andrews (1952) estimated that corporate donations fell by $\$ 52$ million in 1946, but this downturn proved temporary as postwar prosperity continued. By 1947, corporate donations reached an estimated $\$ 241$ million - a level that was generally maintained until 1951 , when Congress reintroduced the excess profits tax during the Korean conflict.

Several arguments have been made about why the end of the war and the repeal of the excess profits tax did not cause an even more precipitous drop in corporate donations. First there were increased philanthropic needs in education, which were similar to the situations addressed by the great individual philanthropists of the late 19th century (Wren, 1983). The G.I. bill helped millions of people to attend college for the first time, putting a strain on the educational resources of the country. Also, many corporations saw widespread support of education as a way of furthering their own goals of obtaining highly skilled workers and maintaining the positive image that they had developed during the war. Sloan (1951) argued that businesses should support education because "in its own interests enterprise should support the sources from which fundamental knowledge flows" (p. 15). The growing concern about the Soviet threat also facilitated corporate support of education. Heald (1970) argued that after the war, education was seen as the "most fertile field of protection against creeping socialism" (p. 207)—donations to education could help protect the country against the "Red Menace."

In 1949, another major event further legitimated corporate philanthropy: The American Bar Association Committee on Business Corporations proposed a model corporation statute to all the states. Included in this model law was a section that explicitly allowed corporations to make donations up to the limits of the IRS regulations without having to show relatedness. Between 1945 and 1948, seven states joined the nine that had already adopted permissive legislation. By 1951, a total of 27 states had adopted similar legislation. Thus a majority of the states had given corporations the power to do what the federal government had implicitly recognized through the IRS code.

By the time the Korean conflict ended, annual corporate giving had regularly exceeded $\$ 250$ million (Bremner, 1987). At this level, corporate philanthropy had become a very visible part of the American landscape. However, there was one additional legal event that would formalize corporate philanthropy's status as legitimate business behavior. 


\section{THE 1953 A. P. SMITH CASE AND}

\section{THE LEGITIMIZATION OF CORPORATE PHILANTHROPY}

What appears to be the climax of the institutional legitimization of corporate philanthropy came in 1953 when the U.S. Supreme Court let stand the lower court ruling in A. P. Smith Manufacturing Co. v. Barlow et al. In this case, the company had donated $\$ 1,500$ to Princeton University for general use and without any obvious financial benefit to the company. A group of stockholders challenged the donation and New Jersey's 1930 passage of permissive legislation, stating that management did not have the right to give away stockholders' funds. The New Jersey Supreme Court had ruled that the existence of the New Jersey legislation gave the company the right to make the donation unencumbered by any relatedness criteria. By refusing to hear the case, the U.S. Supreme Court upheld the New Jersey legislation, although it did not comment on the legality of philanthropy per se.

In retrospect, the ultimate effect of this ruling was to declare dead the doctrine of ultra vires (concerning corporate philanthropy). However, this view needed to be validated by history before it became commonly accepted. Eells (1956) argued that this decision did not settle the issue completely:

In some states, for example, the narrower common law rule still prevails and donors in such jurisdictions may be limited in the scope of corporation giving. Directors in these states may still be limited in the scope of corporation giving and as a result are understandably hesitant to risk stockholders suits by taking philanthropic action. (p. 19)

Yet by 1970 , the case was seen more definitively as a precedent. Heald (1970) argued that the A. P. Smith decision "went a long way to end doubts and uncertainties supporting a marked expansion of contributions in the 1950s" (p. 218). Further evidence of the evolving impact of this case comes from Bremner's (1987) statement about it. Speaking specifically of contributions to education, he said the case clarified "the right of corporations to make contributions" (p. 229).

Although the institutional evolution of corporate philanthropy essentially ended with the $A$. P. Smith case, the growth of corporate charity did not. By 1960, 46 states and territories had adopted explicit corporation legislation that allowed corporate philanthropy. ${ }^{1}$ Events of the subsequent three decades have continued the progress of corporate giving (in 1991, such philanthropy amounted to $\$ 6.1$ billion; see U.S. Government Printing Office, 1993). However, the ruling in the $A$. P. Smith case did end an era. 
By letting the lower court ruling stand, the U.S. Supreme Court, in effect, set aside a 70-year-old legal precedent. In so doing, the Supreme Court put its imprimatur on corporate philanthropy as a legitimate part of the conduct of business. Epstein (1987) argues that the law and its regulatory apparatus are an important method "by which ever-escalating public expectations concerning acceptable business behavior are articulated and implemented" (p. 102). By 1953, the American public had generally accepted corporate philanthropy as appropriate behavior for business. It can be argued that the Supreme Court ruling in the A. P. Smith case institutionalized more formally what the society at large already believed.

\section{Discussion}

\section{PHILANTHROPY AS A LEGITIMATED ACTIVITY}

The previous case material (see the chronology of the key elements in Table 1) suggests that there were forces in the environment that either supported or restricted corporate philanthropy over time (cf. Lewin, 1951). A summary of the elements that drove the evolution of corporate philanthropy can be found in Figure 1. During the 70-year period described in the preceding section, the forces that restrained the development of corporate philanthropy were defeated in two ways. First, in terms of the legal restraining forces, by means of a contagion of legitimacy (Zucker, 1988), courts and legislatures slowly eroded the underlying doctrines (ultra vires and relatedness). Second, the restraining forces were overwhelmed by a wide variety of driving forces stemming from the extreme needs of wartime and depressions to the subtler effects of federated philanthropy programs. The driving forces were the result of causes ranging from elements in the greater society to the strategic uses of public policy by specific business or charitable organizations to the actions of individual actors.

The concept of institutional legitimacy helps us understand the evolution of corporate philanthropy. This discussion of institutional legitimacy is unique because we are not concerned with the legitimacy of a single organization or even a class of firms. Rather, we are concerned with the legitimacy of a class of business firm behaviors. Scott and Meyer (1983) defined something as legitimate when "no question could be raised" (p. 201) about it. Through evolution, corporate philanthropy has changed from a behavior about which institutional actors raised several questions 
Table 1

Chronology of the Key Elements in the Evolution of Corporate Philanthropy

\begin{tabular}{|c|c|c|}
\hline Period & Negative elements & Positive elements \\
\hline $1875-1900$ & $\begin{array}{l}\text { Legal precedence/constraints } \\
\text { Ultra vires } \\
\text { Antibusiness sentiment (e.g., } \\
\text { "tainted money") } \\
\text { Laissez-faire capitalism }\end{array}$ & $\begin{array}{l}\text { Development of company towns and } \\
\text { YMCA facilities } \\
\text { Urbanization } \\
\text { Immigration } \\
\text { Wealthy philanthropists } \\
\text { Development of tax-exempt organizations }\end{array}$ \\
\hline $1900-1915$ & $\begin{array}{l}\text { Urbanization } \\
\text { Legal constraints on donation } \\
\text { expenses }\end{array}$ & $\begin{array}{l}\text { Antibusiness sentiment } \\
\text { Increase in number of charitable } \\
\text { organizations } \\
\text { Scientific philanthropy }\end{array}$ \\
\hline $1915-1920$ & $\begin{array}{l}\text { Continued legal restrictions on } \\
\text { deductible expenses }\end{array}$ & $\begin{array}{l}\text { War needs } \\
\text { Red Cross "dividend } \\
\text { Some enabling legislation at the state } \\
\text { and federal levels } \\
\text { Justice Hughes's opinion }\end{array}$ \\
\hline $1920-1929$ & $\begin{array}{l}\text { Continued legal restrictions on } \\
\text { deductible expenses }\end{array}$ & $\begin{array}{l}\text { Community Chest movement } \\
\text { U.S. Chamber of Commerce recognition } \\
\text { of social responsibility } \\
\text { No ultra vires rulings }\end{array}$ \\
\hline 1929-1939 & $\begin{array}{l}\text { Roosevelt's resistance to the } \\
\text { business charity donation } \\
\text { deduction } \\
\text { Conservative IRS interpretation } \\
\text { of charitable expense } \\
\text { deductions }\end{array}$ & $\begin{array}{l}\text { The Great Depression } \\
\text { Widespread social and political support } \\
\text { for business charity donation deduction } \\
\text { Business involvement in the Organization } \\
\text { for Unemployment Relief } \\
\text { Business charity donation becomes part } \\
\text { of the IRS regulations }\end{array}$ \\
\hline $1939-1953$ & & $\begin{array}{l}\text { Wartime prosperity } \\
\text { War needs } \\
\text { Excess profits taxes } \\
\text { Postwar needs } \\
\text { Influx in enrollment in higher education } \\
\text { ABA Model Corporations statute } \\
\text { State-level enabling legislation }\end{array}$ \\
\hline 1953 & & A. $P$. Smith ruling upheld \\
\hline
\end{tabular}

(legal and otherwise) to a behavior that has become the top of the pyramid of corporate social responsibility (Carroll, 1991).

Taken together, the previously described concepts explain the evolution of corporate philanthropy. This article asserts that the dynamism of 


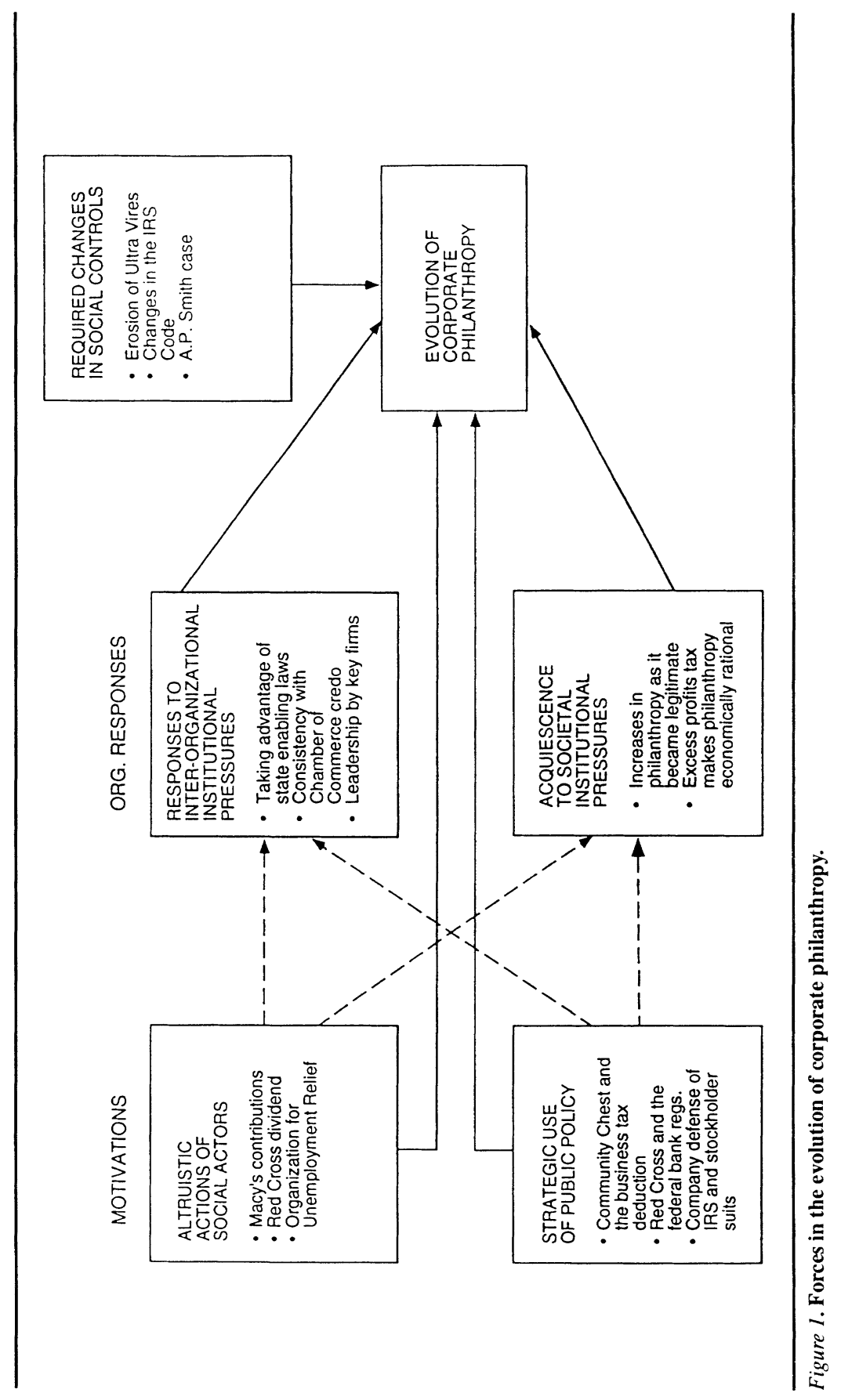


the driving and restraining forces around corporate philanthropy was actually a conflict across several decades about the legitimacy of corporate donations. The ruling in the $A$. P. Smith case can be thought of as the victory of the driving forces in the battle over the legitimacy of corporate donations. The results of that legitimization include the billions of dollars (e.g., Platzer, 1990) that firms donate annually to charitable causes and the increasing promotion of these activities as competitive advantage.

An examination of these elements in light of the theoretical perspectives mentioned earlier provides us the means to fully understand the evolution of corporate philanthropy. By definition, the stronger the forces are trying to maintain a social element, the more force required to change that element (Lewin, 1951). In the case of corporate philanthropy, several social elements (including legal pressures) attempted to forestall the changes in the institutional structure surrounding corporate donations. However, the driving forces incrementally overcame the restraining pressures both directly and through Zucker's (1988) contagion of legitimacy. The forces attempting to change the role of corporate philanthropy can be classified into five sets of pressures. These pressures were (a) the altruistic actions of social actors (cf. Reilly, 1990), (b) the strategic use of public policy by charitable organizations and business firms (e.g., Mitnick, 1981; Wood, 1986), (c) responses by firms to interorganizational institutional pressures (Dimaggio \& Powell, 1983), (d) organizational acquiescence to societal institutional pressures (cf. Oliver, 1991), and (e) changes in the controls governing the social structure (Smelser, 1968). ${ }^{2}$

\section{Altruistic Actions of Social Actors}

Reilly's (1990) arguments about social activism and economic growth help us to understand why particular social actors pushed for the legitimization of corporate philanthropy. He suggested that "once the present seems relatively secure, people can focus on the future" (p. 17). While the United States went through the upheavals of industrialization, immigration, urbanization, war, and depressions, the overall economy grew rapidly. Although there were still large numbers of poor people during each of these periods, there were sufficient numbers of people for whom subsistence was no longer a question. These actors could turn (as many did) to altruism and social activism, including activities related to corporate philanthropy. These actors were responsible for many changes including various wartime and Depression-era business charity drives, the Red Cross dividend, the business charitable donation deduction drive, and the philanthropy-enabling legislation on both the state and the federal levels. 
Some of the most powerful changes in the evolution of corporate philanthropy were the result of the actions of single actors rather than coordinated advocacy. The Red Cross dividend caused many firms to open up to the idea of corporate giving. Justice Hughes's comments about philanthropy and firm survival appear to have appreciably increased corporate giving during the second Red Cross campaign. The U.S. Chamber of Commerce's statement on the social responsibility of business reframed the way in which many managers viewed their role in society. The American Bar Association (ABA) Model Corporations Code facilitated many states' adoption of permissive legislation. In each of these situations, the key actors had one thing in common: All had achieved a high degree of social legitimacy. The Red Cross was regarded highly before the war, and its position was solidified when, in 1917, President Wilson called a special White House conference to discuss how the country should support its efforts. Justice Hughes was a retired member of the U.S. Supreme Court. The Chamber of Commerce was seen as the representative of business interests. At the time of the model corporations code, the ABA was perceived as the dominant voice of the legal profession in this country. Additionally, the ABA and the Chamber of Commerce national office conferred legitimacy on the activities of others (cf. Dimaggio \& Powell, 1983). Thus the altruistic actions of these and other highly legitimated actors went a long way toward changing the status of corporate philanthropy.

\section{Strategic Use of Public Policy by Charitable and Business Organizations}

Another form of advocacy for the legitimization of corporate philanthropy occurred at the single organization level. Mitnick's (1981) and Wood's (1986) arguments on the strategic use of public policy are helpful in examining this advocacy. These writers argued that organizations can make use of legislation and public policy for their own strategic ends. There is evidence of such use throughout the history of corporate philanthropy. Interestingly, the most extensive users of public policy for strategic ends were not business organizations but charitable groups. At times the YMCA, the Red Cross, and the Community Chest all engaged in public policy-related activities aimed at making it easier for corporations to donate to their respective causes.

The most far-reaching public policy action was the passage of the business charitable donation tax deduction. Much of the credit for the passage of this law must be given to the national organization of the 
Community Chest. The Red Cross was instrumental in obtaining legislation that allowed federally chartered banks to donate to its World War I drive. In both of these cases, business organizations were also involved in advocating for looser controls on their philanthropic activities. However, because business organizations did not wish to be viewed as "buying" legitimacy through philanthropy, they often played a secondary role in public policy advocacy. The most visible business philanthropists supported activities with their own wealth (e.g., Carnegie, Rockefeller, Stanford, and Sage) or as part of government-sanctioned groups (e.g., Wilson's World War I business conference on the Red Cross) and as appointees (e.g., Gifford of AT\&T as head of the Organization for Unemployment Relief).

There was some advocacy by business organizations for expanded use of philanthropy, but it was decidedly low key. In general, business organizations let social organizations take the overt lead in advocating additional freedom in terms of corporate philanthropy. Business firms concentrated their strategic use of public policy in their battles in the courts. By defending themselves against stockholder suits and IRS tax-based challenges to philanthropic activities, these firms expanded their discretion in corporate giving while maintaining a low profile. In this way, these activist business firms could expand the rules surrounding corporate philanthropy without drawing large amounts of attention to themselves.

\section{Organizational Responses to Interorganizational Institutional Isomorphic Pressures}

This article suggests that much of the impetus on business organizations to expand the role of corporate philanthropy resulted from interorganizational institutional isomorphic pressures (Dimaggio \& Powell, 1983). These authors suggested that organizations are so alike because of three sets of forces in the institutional environment that push firms to be similar or "isomorphic" (p. 147). The isomorphic pressures are classified as coercive (the use of force, legal or otherwise), normative (the imposition of value-driven pressures), or mimetic (the imposition of pressure to imitate some leading institutional actor). Although no firms explicitly forced others to engage in philanthropic behavior, normative and mimetic isomorphic interorganizational pressures on firms made the practice of philanthropy more pervasive.

By the end of the 1920s, firms were experiencing interorganizational isomorphic pressures to engage in corporate philanthropy. By passing enabling legislation, the states that did so not only gave firms the oppor- 
tunity to donate if they chose, they exerted pressure on firms to donate by incorporating corporate philanthropy into the states' views of a model corporation. By promulgating a code of ethics that said corporations had a duty to their communities, the national Chamber of Commerce also gave its approval for donations while placing normative pressure on firms to give. Finally, as large, highly visible firms such as AT\&T engaged in more and more philanthropy, other firms appear to have perceived mimetic isomorphic pressures to behave in a similar way. As firms received more pressure to engage in corporate philanthropy, they were more likely to exert pressure on the institutional rules to make the practice legitimate.

The Acquiescence of Firms to

Societal Institutional Pressures

Another part of the evolution of corporate philanthropy can be traced to the acceptance by business firms of the rising tide of public and legal sentiment favoring corporate giving. Managers reacted to these stakeholder pressures in a way consistent with Oliver's (1991) arguments about organizational responses to institutional pressures. Oliver (1991) suggests that there are several antecedent conditions that predict when firms are more or less likely to attempt to acquiesce to institutional forces. She looks at five sets of conditions: the cause of the pressures, the presence of constituents (stakeholders), the content of the institutional pressures, the type of control the institutional forces apply, and the context within which the institutional forces are applied. She then uses these antecedents to predict how firms are likely to respond to institutional pressures ranging from acquiescence to manipulation. Oliver's model suggests that because of the ways that the institutional pressures for corporate philanthropy grew, business firms were likely to acquiesce to the pressure.

During the early part of the 20th century, the pressures on firms to engage in philanthropy were mounting. In Oliver's terms, because firms could increase their social legitimacy and improve their economic prospects by acquiescing to the rising tide favoring corporate philanthropy, it was logical that they did so. As the balance among constituents changed from the majority opposing corporate philanthropy to the majority favoring it, firms responded by acquiescing to the tide. After the national Chamber of Commerce proclaimed that firms had a responsibility to their communities, the content of the pressure for corporate philanthropy became more consistent with those firms that agreed with the principle. This agreement made acquiescing to the pressure for corporate philanthropy easier. As the tax structure made compliance with the institutional 
pressures for corporate philanthropy more economically attractive and as isomorphic pressures increased the diffusion of this behavior, firms also increased their acceptance of corporate philanthropy. Because the expansion of corporate philanthropy appears to have been (in the main) positive for firms (e.g., increased legitimacy, socially acceptable advertising, fulfillment of the "social contract," etc.) Oliver's (1991) model would predict firms' acquiescence to the institutional pressure for change.

\section{Changes in the Controls Governing the Social Structure}

Smelser (1968) argues that social elements will not change unless the social controls on the element themselves are changed. No amount of advocacy will change a social element if the social controls of that element are intractable. In this case, the ultimate social controls were legal. In 1883, the courts applied the ultra vires doctrine to corporate "charity." Regardless of how that doctrine was stretched and expanded, prior to the $A$. $P$. Smith case, corporate philanthropy was still viewed as less than completely legitimate business behavior. Even when the income tax laws allowed deductions for corporate donations, the practice was not universally accepted. This was true in part because Franklin Roosevelt (a symbol of social control through state authority) had opposed these deductions. The court system is important in "shaping the institutional framework within which organizations of varying types operate" (Scott, 1987, p. 509); therefore, because it was the court that declared the practice illegitimate, it was necessary for a court to formally reverse that declaration. Even though corporate philanthropy had received tacit approval from society, the courts served the role of formal conveyor of legitimacy.

However, not just any court could confer legitimization on corporate giving. The U.S. Supreme Court is the only judicial body whose rulings have an impact on the entire American legal system. Although on occasion the Supreme Court has reversed its own earlier rulings, the general trend is that these decisions themselves become institutionalized. The only way the formal social controls on corporate philanthropy could be changed was through a Supreme Court ruling to that effect. It took almost 20 years after the income tax provision became law for a case concerning the legality of corporate philanthropy per se to reach the Supreme Court. It is likely that this delay was the result of the general view of the American public that the IRS change had legitimated (modified the social controls surrounding) the practice. However, not until the Supreme Court had let the A. P. Smith ruling stand could all questions concerning the legitimacy of corporate philanthropy be considered resolved. 
Figure 1 summarizes how the driving forces affected the evolution of corporate philanthropy. Every set of driving forces (represented by a few key elements as examples) had a direct effect on the legitimization of corporate philanthropy. As examined earlier, each set of forces either directly reduced the potency of the forces restraining corporate philanthropy or established a pathway by which the contagion of legitimacy "flowed."

There may have been some indirect effects on the evolution of corporate philanthropy as the result of relationships between some of the sets of forces. Through the use of dashed lines in Figure 1, I propose what appears to have happened between and among these sets of forces. Building on some of Wood's (personal communication, 1994) work, I have organized four of the five sets of forces as either motivations or organizational responses. The motivations group addresses both personal value-driven (altruistic) and instrumental motives for social performance (cf. Wood, 1991). The data suggest that the actors in the evolution of corporate philanthropy participated in the process both out of their own self-interest and out of what may have been more societally oriented motivations. Figure 1 also shows how, given the motivations, these actors responded to both institutional pressures stemming from interorganizational sources and those stemming from society at large. Further research might be able to clarify what reciprocal effects, if any, the responses to institutional pressures had on the motivations.

\section{TOWARD A MORE GENERAL THEORY}

CONCERNING INSTITUTIONAL STRUCTURE CHANGE

What does the evolution of corporate philanthropy say to a more general theory of change in the institutional structure? The foregoing analysis leads us to several conclusions. First, in the most basic sense, we see that as with any change, the forces facilitating the change must outweigh those restraining it. However, in the case of changes in the institutional structure, the first force to be overcome was the inertia that these elements develop from being a stable element in the overall social fabric (e.g., Granovetter, 1985). Concerning the change in the role of corporate philanthropy, it appears that several environmental shocks (e.g., wars and depressions) coupled with chronic problems from industrialization and urbanization were necessary to push corporate philanthropy's evolution forward. Although the contagion of legitimacy (Zucker, 1988) 
appeared able to facilitate more changes once the legitimization of corporate philanthropy had been initiated, it is not clear that the contagion of legitimacy itself could have gotten the ball rolling. It is the role of shocks and discontinuities in the social structure that may prove fruitful for future research on institutional change.

Second, we can see an interesting parallel from the previous analysis between the multiple pressures that stakeholders place on a firm and the multiple pressures that social elements and actors place on institutional rules. In a stakeholder analysis of an organizational issue (e.g., Freeman, 1984), managers assess the varying demands stakeholders place on the firm and attempt a strategy that placates as many as possible without offending any more than necessary. It is clear that there were several actors who had stakes in the outcome of the evolution of corporate philanthropy and that there was some coordinated actions among the actors. However, it is not clear how the conflicting demands of the stakeholders surrounding corporate philanthropy were worked out. Given the wide variety of actions, actors, and related phenomena described previously, the coordinated activity that occurred does not appear sufficient to be considered an overall negotiated order (cf. Day \& Day, 1977; Nathan \& Mitroff, 1991). Although the process seems to have been some sort of an Adam Smith-like "invisible hand" (Smith, 1776), the actual mechanisms that helped resolved these conflicting stakeholder demands also will prove to be an interesting topic for future research.

Finally, even though the solution to the conflicting elements (i.e., the institutional legitimacy of corporate philanthropy) could be argued as functional for society, not all members of American society supported it (e.g., Friedman, 1962). What also will be interesting is to further examine the mechanisms that allow society to change its own structure as old rules become obsolete - even when the desire for change is not universal. We know that institutional rules can exist even when the majority of a society's citizens do not support them (e.g., Apartheid in South Africa); but in that case, violent change is often the outcome. In situations where much less intense institutional structural changes are sought, the mechanisms for changing those rules present several opportunities for study. Specifically, with corporate philanthropy, we saw that the actions of several institutional actors addressing the problem from several different directions appeared necessary to facilitate the change. Additional research will clarify whether the multiplicity of advocates/perspectives is necessary for all major institutional structure changes or whether there is something unique about the role of corporate philanthropy. 


\section{Conclusion}

The purpose of this article was to examine change in the institutional role of corporate philanthropy. To organize that study, this article has examined the evolution of corporate philanthropy's status from illegal to expected behavior on the part of business. Using institutional theory (e.g., Dimaggio \& Powell, 1983; Meyer \& Rowan, 1977; Zucker, 1988), this article has explained how the confluence of elements driving for the legitimization of corporate philanthropy overcame those that tried to restrain this evolution through a contagion of legitimacy. This analysis can help us to understand how corporate philanthropy evolved to its present state in which businesses annually give billions of dollars to charity.

Studying the evolution of corporate philanthropy informs our theory of change in the institutional structure of business. Although other research has examined the institutional evolution of stakeholder management (Hill \& Jones, 1992), we have virtually no research on the evolution of other types of corporate social performance. This article helps fill that void. Most of the research on the relationship between business and the institutional structure has investigated how that structure affects organizations (e.g., Leblebici et al., 1991; Singh et al., 1986). The focus of the this study is on how the elements of the structure themselves changed. This analysis can help us understand that even though institutional rules are by nature inertial, institutional structure change is possible. The change in corporate philanthropy's role was based on both widespread social forces and the actions of individuals or single organizations. The analysis also supports several theoretical perspectives including both the strategic use of public policy arguments (e.g., Wood, 1986) and Oliver's (1991) predictions about organizational manipulation of the institutional environment.

This article also has some implications for managerial practice. Oliver (1991) outlined a theory of organizational responses to institutional pressures suggesting that firms have alternatives besides complete acquiescence. For managers to have discretion in their dealings with the institutional structure, they must understand its nature. To understand the nature of the institutional structure, one must first understand its history (Fligstein, 1990; Jackson, 1990). The evolution of corporate philanthropy teaches us about the general nature of institutional change and the specifics of corporate philanthropy's evolution. If managers understand how corporate philanthropy and the other elements of corporate social performance have evolved, they may be better able to judge what is expected of them and their firms today. 
Finally, the article suggests some future research directions concerning the nature of institutional structural change itself and proposes several questions for further study. By further examining the role that changes in social and institutional structures play in creating a context for organizations, we can better understand how the elements of organizations themselves change.

\section{NOTES}

1. As of this writing, all U.S. states and territories have enacted legislation that explicitly allows corporate philanthropy.

2. It should be noted that no effort has been made to categorize the forces attempting to restrain the evolution of corporate philanthropy. One possible way to examine these forces in future research is to look at the tension between such paradigms as the "gospel of wealth" of the social Darwinists and more communitarian approaches.

\section{REFERENCES}

Andrews, F. E. (1952). Corporation giving. New York: Russell Sage.

Aram, J. D. (1989). The paradox of interdependent relations in the field of social issues management. Academy of Management Review, 14(2), 266-283.

Berger, P. L., \& Luckmann, T. (1967). The social construction of reality. New York: Doubleday.

Bremner, R. H. (1987). American philanthropy. Chicago: University of Chicago Press.

Brinson Railroad Co. v. Exchange Bank et al., 16 Ga. App. 425, 85 S.E. 634 (1915).

Carroll, A. B. (1991). The pyramid of corporate social responsibility: Toward the moral management of organizational stakeholders. Business Horizons, 34(4), 39-48.

Davis, K. (1973). The case for and against business assumption of social responsibilities. Academy of Management Journal, 16, 312-322.

Davis et al. v. Old Colony Railroad Co., 131 Mass. 258 (1881).

Day, R., \& Day, J. V. (1977). A review of the current state of negotiated order theory: An appreciation and a critique. Sociological Quarterly, 18, 126-142.

Dimaggio, P. J., \& Powell, W. W. (1983). The iron cage revisited: Institutional isomorphism and collective rationality in the organizational field. American Sociological Review, 48, 147-160.

Eells, R.S.F. (1956). Corporation giving in a free society. New York: Harper Bothers.

Epstein, E. M. (1987). The corporate social policy process: Beyond business ethics, corporate social responsibility and corporate social responsiveness. California Management Review, 29(3), 99-114.

Fligstein, N. (1990). The transformation of corporate control. Cambridge, MA: Harvard University Press.

Freeman, R. E. (1984). Strategic management: A stakeholder approach. Boston: Pitman.

Friedman, M. (1962). Capitalism and freedom. Chicago: University of Chicago Press. 
Ghent, W. J. (1902). Our benevolent feudalism. New York: Macmillan.

Giddens, A. (1982). Profiles and critiques in social theory. London: Macmillan.

Gladden, W. (1895). Tainted money. Outlook, 52, 886-887.

Granovetter, M. (1985). Economic action and social structure: The problem of embeddedness. American Journal of Sociology, 91(3), 481-510.

Heald, M. (1970). The social responsibility of business: Company and community 19001960. Cleveland, OH: Case Western Reserve University Press.

Hernes, G. (1976). Structural changes in social processes. American Journal of Sociology, $82,513-547$.

Hill, C.W.L., \& Jones, T. M. (1992). Stakeholder and agency theory. Journal of Management Studies, 29(2), 131-154.

Holt (E. M.), Plaid Mills, Inc., 9 B.T. A. 1360 (1928).

Hughes, E. C. (1939). Institutions. In R. E. Park (Ed.), An outline of the principles of sociology (pp. 283-346). New York: Barnes \& Noble.

Hutton v. West Cork Railway Co., Vol. 23, The Law Reports, Chancery Division, p. 654 (1883).

Jackson, J. E. (1990). Institutions in American society: An overview. In J. E. Jackson (Ed.), Institutions in American society: Essays in market, political and social organizations (pp. 9.30). Ann Arbor: University of Michigan Press.

Jeperson, R. L. (1989). Institutions, institutional effects and institutionalization. In W. W. Powell \& P. Dimaggio (Eds.), The new institutionalism in organizational analysi (pp. 143-163). Chicago: University of Chicago Press.

Leblebici, H., Salancik, G. R., Copay, A., \& King, T. (1991). Institutional change and the transformation of interorganizational fields: An organizational history of the U.S. radio broadcasting industry. Administrative Science Quarterly, 36(3), 333-363.

Lewin, K. (1951). Field theory in social science: Selected theoretical papers (D. Cartwright, Ed., Trans.). New York: Harper.

Lloyd, C. (1986). Explanation in social history. New York: Basil Blackwell.

Main v. C. B. \& Q. Railroad Co., 109 Iowa 260, 70 N.W. 630, 80 N.W. 315 (1899).

Majors, J. A., Co., 5 B.T.A. 260 (1926).

McCaw, T. K. (1984). Prophets of regulation. Cambridge, MA: Harvard University Press.

Meyer, J. W., \& Rowan, B. (1977). Institutionalized organizations: Formal structure as myth and ceremony. American Journal of Sociology, 83, 340-363.

Mitnick, B. (1981). The strategic uses of regulation and deregulation. Business Horizons, 24(2), 71-83.

Mowry, G. E. (1972). The progressive era, 1900-20, the reform persuasion. Washington, DC: American Historical Association.

Nathan, M L., \& Mitroff, I. I. (1991). The use of negotiated order as a tool for the analysis and development of an interorganizational field. Journal of Applied Behavioral Science, 27(2), 163-180.

Old Mission Portland Cement Co. v. Helvering, 293 U.S. 289 (1934).

Oliver, C. (1991). Strategic responses to institutional processes. Academy of Management Review, 16(1), 145-179.

Parsons, T. (1960). Structure and process in modern societies. Glencoe, IL: Free Press.

People ex rel. Metropolitan Life Insurance v. Hotchkiss, 136 App. Div. 150, 129 (1909).

Platzer, L. C. (1990). Survey of corporate contributions. New York: Conference Board.

Poinsett Mills, 1 B.T.A. 6 (1926).

Proprietors of the Charles River Bridge v. Proprietors of the Warren Bridge, 36 U.S. 11 Peters 420 (1837). 
Reilly, W. K. (1990, Fall). The green thumb of capitalism: The environmental benefits of sustainable growth. Policy Review, 54, 16-21.

Scott, W. R. (1987). The adolescence of institutional theory. Administrative Science Quarterly, 32, 493-511.

Scott, W. R., \& Meyer, J. W. (1983). The organization of societal sectors. In J. Meyer \& W. R. Scott (Eds.), Organizational environments: Ritual and rationality (pp. 129-154). Beverly Hills, CA: Sage.

Singh, J. V., Tucker, D. J., \& House, R. J. (1986). Organizational legitimacy and the liability of newness. Administrative Science Quarterly, 31, 171-193.

Sloan, A. P., Jr. (1951, June 2). Big business must help our colleges. Colliers, pp. 13-15.

Smelser, N. J. (1968). Essays in sociological explanation. Englewood Cliffs, NJ: PrenticeHall.

Smith, A. (1776). Wealth of nations: An inquiry into the nature and causes of the wealth of nations. London: Printed for W. Strahan and T. Cadell in the Strand.

Smith, A. P., Manufacturing Co. v. Barlow et al., 26, N.J. Super. 1061953 affirmed, 98 ALT 20 581; 346, U.S. 861 (1953).

Starbuck, W. (1976). Organizations and their environments. In M. Dunnette (Ed.), Handbook of industrial and organizational psychology (pp. 1069-1123). Chicago: Rand McNally.

Steinway v. Steinway \& Sons et al., 17 Misc. Rep 43, 40 N.Y. Supp 718 (1896).

Superior Pocahontas Coal Co., 7 B.T.A. 380 (1927).

U.S. Government Printing Office. (1993). Statistical Abstracts of the United States, 1992. Washington, DC: Author.

Wood, D. J. (1986). Strategic uses of public policy, business and government in the progressive era. Boston: Pitman.

Wood, D. J. (1990). Business and society. New York: Scott Foresman/Little, Brown.

Wood, D. J. (1991). Corporate social performance revisited. Academy of Management Review, 16(4), 691-718.

Worthington v. Worthington, 91 N.Y. Sup. 443 (1905).

Wren, D. A. (1983). American business philanthropy and higher education in the nineteenth century. Business History Review, 57, 321-347.

Zald, M. (1990). History, sociology, and theories of organization. In J. E. Jackson (Ed.), Institutions in American society: Essays in market, political and social organizations (pp. 81-108). Ann Arbor: University of Michigan Press.

Zucker, L. (1988). Institutional patterns and organizations, culture and environment. Cambridge, MA: Ballinger. 